\title{
Chapter 6 \\ Sindo, Environment and the Politics \\ of Fishing in North Korea
}

\begin{abstract}
Sindo island is in the mouth of the Amnok (Yalu in Chinese) River at the border between North Korea and the People's Republic of China. Reclaimed from the estuary of the river in 1971, a cooperative of fisher people from older fishing communities and enterprises along the western coast of North Korea was created to serve as a model community and model example of development at this time. Kim Il Sung himself made repeated visits between 1971 and 1976, during a period when North Korean politics sought to reconfigure landscape and developmental possibility through a series of what are called 'Great Nature Remaking Projects'. North Korea's fishing industry was to be reconfigured so as to focus on resources further out to sea, fishing practice and knowledge was to be further developed and a series of cooperatives were to be the institutional basis for the sector. By the 1990s, fishing cooperatives such as Sindo had been forgotten in the collapse of North Korean capability and bureaucracy and in the 2000s, the fishing industry has been co-opted by the Korean Peoples' Army and a network of fishery stations dedicated to industrial fishing and resource production built. This meant that Sindo became even more peripheral to the political and institutional mind. This chapter explores this history, context and strategies the fisherpeople of Sindo might use to maintain their livelihoods and connections to the vibrant and lively fishing matters that once sustained and gave impetus to them. In Sindo and in other places within North Korea are fishing matters as vibrant and energetic as local political sensibility and aspiration are lively?
\end{abstract}

Keywords North Korea • North Korean fishing communities • Sindo • Amnok River $\cdot$ Environmental change

With this penultimate chapter, this book returns to the Korean Peninsula, but does so with a shorter historical frame and some of the perspectives gained from fieldwork in North Korea's neighbours both to the south and north. Readers will have encountered in the preceding chapter the extraordinary survivals of communities in China and South Korea who are focused on fishing and the products of the sea, extraordinary for the challenges faced by them generated by both environmental 
and politico-economic issues. This book has attempted to detail as best it can, the impact of human development over the centuries, but especially the last two centuries on fish and their watery landscapes. The nineteenth and twentieth centuries saw the rise of technological and industrial fishing, connected to the power of mercantilist and colonialist Capital. The logics both of Capitalism and Empire began a stripping of the oceans in the nineteenth century, but this developed into a truly extraordinary industrial process by which fish can now in the twenty-first century be located by GPS satellite from space, extracted from the sea at all levels and even stripped from the ocean floor or beneath it. These fish can be produced into abstracted and reformed products, their flesh and material reconfigured into different shapes and textures, while still at sea so these new matters are ready for computerised logistics and shipping to disperse them across the planet. In the previous chapter, new technologies such as refrigeration meant that fishing communities could venture further from the coast, beginning work in the deep seas, pressuring for the first time fish populations in deeper waters. Refrigeration in conjunction with steam power hugely altered the effort and energy placed into extraction by industrialising fishing enterprises. These technologies were later embedded in new fishing practices such as the use of motherships and deep-sea trawling. Geopolitics following the 1914-1918 war meant that Japan was gifted the League of Nations mandate over Germany's former South Pacific colonies, giving it an opportunity to practice using these technologies and logistics. It would later deploy such infrastructure and technology across the empire it built in East Asia and the wider Pacific before 1945. After the conclusion of the war in the Pacific in 1945 and Japan's defeat, global American geopolitical interests meant that the United States was very concerned to assert what it called 'freedom of the seas' across the planet. This inadvertently meant that it had to guarantee the freedom of the deep seas for all other nations, including its deadly enemy between 1941 and 1945. More than that the United States was very concerned that Japan be both as cheap as possible to occupy and rebuild following 1945 and a useful bulwark and ally against world communism in Asia and the Pacific. Inexplicably, this would result in the United States essentially selling out some of its own Californian tuna canning and fishing interests in order to allow Japan to build a canning factory on one its former colonies (now known as American Samoa) and to import cans of tuna caught by Japanese boats into the 50 states of the continental United States of America.

These new geopolitically connected, technologically advanced fishing landscapes put not just extreme pressure on fish populations, often causing them to collapse under the power and agency of Maximum Sustainable Yield, but also fishing communities. Most recently, this power has been seen in fishing communities in Africa who are out competed and displaced by the factory boats of the European Union and others. Fishing communities in this book have been enormously challenged by the changes to the landscape and the fishing ecosystems created and reconfigured by this new industrial empire of fishing. In tandem with this pressure on fish stocks and populations have been wider pressures focused on watery and maritime environments by huge growth in human population and the 
wider global economy. This second decade of the twenty-first century has brought enormous dead zones in the global oceans, with no or little oxygen, a product of industrial farming and sewage discharges. It has also brought coral bleaching, sea temperature rise, sea level rise and ocean acidification, products of climate change and wider environmental crisis. Finally, and perhaps most resonant in the public mind the oceans have simply been filled with disposable and non-biodegradable waste, particularly plastics. While the world is familiar with the fact that human waste and chemical products, historically DDT and Chlorofluorocarbons (CFCs), can reach the furthest parts of our globe and wreak havoc there, plastic is a great deal more visual and present. It is a lively and active material which persists in global ecosystems, stuck in the throats of turtles, twisting up in the intestines of fish and cetaceans, spread over the beaches of remote islands and caught in the North Pacific Gyre, an ocean current in the middle of the ocean so polluted it is now publicly familiar as the Great Pacific Garbage Patch. The fishing communities encountered in the previous chapter certainly have been impacted by plastic, this was obvious in the case of Tong Shui Gou (通水沟) on the Liaodong peninsula, whose catch witnessed by this author was predominantly plastic waste. Gageodo island in South Korea was impacted by unusual weather and drought during the field visit by the author. All of these communities surely have been affected severely by these environmental changes in the present, and they certainly will be in the years to come, perhaps as climate crisis and sea level rise increases in severity.

North Korea, of course, will not be absent from these challenges, there is no way it will not be subjected to the environmental challenges faced by the rest of the globe in the coming years. In fact, North Korea has already been subject to intense environmental impacts, it is even suggested that one of the driving factors in the nation's economic and environmental collapse in the early 1990s was a series of climactic events and flooding which damaged the nation's vulnerable pump-fed irrigation system and therefore hugely impacted upon its agricultural output, contributing to its terrible famine period. Only 3 years ago, the northern provinces of North Korea were subjected to further intense flooding following unexpectedly heavy rain and 2018 was a drought year which has again impacted agricultural production. ${ }^{1}$ Just at the moment that a nation's ability to feed its population has become a key prerequisite of its governmental offer, North Korea has been delegitimised in the public and media mind due to these impairments. ${ }^{2}$

The developmental history of North Korea does not record that it has been happy to accept failure and the collapse of its own agricultural and developmental systems. Pyongyang following the disasters of the 1990 s, was forced to call for the first time for aid from the non-communist world. ${ }^{3}$ Along with the grain and other aid resources came an influx of agencies of the United Nations and other NGOs whose

\footnotetext{
1"North Korea Floods, Tens of Thousands Displaced," BBC News, September 13th, 2016. Retrieved April 27, 2019 from https://www.bbc.co.uk/news/world-asia-37335857.

${ }^{2}$ Boffey (2019).

${ }^{3} \operatorname{Kim}$ (2011).
} 
focus was the improvement of developmental outcomes for impoverished or challenged nations, recovery from famine and disaster and environmental mitigation. While there is no doubt that North Korea found this period extremely difficult and humiliating as a sovereign power, with hindsight it might be said that in fact, the period was extremely useful when it came to governmentality and developmental repertoire. NGOs such as Triangle Humanitaire, Nautilus and the United Nations Environment Programme (UNEP) as well as the United Nations Development Programme (UNDP), brought an entirely new way of looking at the environment and nature-human relations. ${ }^{4}$ North Korea previously had framed natural matters and environmental issues through the lens of its own highly anthropocentric ideology of Juche and self-reliance which itself was originally predicated on Marxist materialist dialectics. Essentially, this mean that the environment was seen only as a resource and living things in nature not as vibrant materials or energetic matters, but as passive objects to be extracted and deployed entirely to the service of man, The environmental movement which followed the developments of the 1960s in the capitalist West, and notions of sustainability, limits to growth and a finite planet had passed Pyongyang by, disregarding, of course, North Korea's inefficiency and failure to develop an extensive and powerful industrial base. ${ }^{5}$ For the first time North Korea, amidst the chaos of the early $1990 \mathrm{~s}$ encountered these ideas, essentially as a route to survival through the intensely difficult period, referred to by North Korea as the 'arduous march' (the second such march as the first was during the period of guerrilla struggle in the 1930s). ${ }^{6}$

Such environmentally friendly or sustainable techniques have in part allowed North Korea to keep functioning into our present. Visitors to North Korea will see an abundance of solar panels for instance in Pyongyang and in other cities. On the face of it, this was taken as a good sign, that North Korea was developing a real sense that renewable technologies would be vital in the future. ${ }^{7}$ In fact, it has been suggested that the growth in the number of solar panels at home is actually one of the many signs, along with a network of guerrilla markets and small private food kiosks, that Pyongyang has essentially given up on its responsibilities as a state and rather than constantly demonstrating its developmental incapacities has essentially left its population to fend for itself..$^{8}$ There is an abundance of solar panels because the local electricity grid, even in Pyongyang (though it has by accounts become a little better in recent years), is unreliable and often fails, hence citizens must use their initiative to make sure they have electricity. ${ }^{9}$ Other forms of sustainable energy production such as wind power were one of the earliest environmentally friendly technologies brought into North Korea, and although there are a few wind

\footnotetext{
${ }^{4}$ Noland (1997).

${ }^{5}$ Winstanley-Chesters (2014).

${ }^{6}$ Ibid.

${ }^{7}$ Makinen (2016).

${ }^{8}$ Ibid.

${ }^{9}$ Ibid.
} 
turbines, North Korea has never managed to harness a substantial amount of power from them. ${ }^{10}$ In reality when it comes to the countries environmentally friendliness, North Korea has one of the lowest $\mathrm{CO}_{2}$ emissions rates on the planet, not because it is concerned not to impact climate change yet further, but because its industrial base collapsed to such an extent that there is very little functioning that can actually produce excessive $\mathrm{CO}_{2}$ or other emissions. ${ }^{11}$ Organic agriculture in North Korea has become quite an important issue for government. This author has tracked the development of new stock-breeding bases at Sepho, using organic feed and other materials and there is even an organic dairy processing enterprise in North Korea which is seeking to fill the supply gap for organic dairy products in Europe. ${ }^{12}$ However, this use of organic agriculture has not come about because of a Damascene conversion to the cause, but because North Korea's agricultural system used to be one of the most chemical and fertiliser intensive systems on earth, and since the early 1990s and now since the UNSC sanctions have been strengthened, it simply does not have the capital to buy such large amount of fertiliser, nor has it been able to make it locally. ${ }^{13}$ North Korean agriculture was even experiencing a decline in the 1980s due to the impending nutritional death of its soil. Organic and low impact agriculture, therefore, is simply the only form of farming that the nation is now capable of and its environmental benefits for Pyongyang come second.

This period also saw the importation of ideas of conservation and sustainability into North Korea, which focused on the sea and on fishing resources. There is an anecdote about one of the first UNEP meetings in North Korea which touched on the sea, in which having had the idea of maritime conservation explained to him by the official from the United Nations, the Minister of Fisheries exclaimed that this was fantastic as there would now simply be many more useful fish for their boats to catch. ${ }^{14}$ Fish, for North Korea following the difficulties of the 1990s were not something to conserve or leave alone, they were a useful, if not vital, free resource, a commons to exploit with little complicated effort involved in their capture. While North Korea has continued to talk about notions of conservation and environmental protection at sea, and the mitigation or reduction of harms in the water, little sense has been gained of any movement on the institutions of the nation's idea of what such notions actually are, other than intrinsically connected to the needs and hopes of man, rather than the interests of fish.

In the previous chapters of this book, readers will have encountered multiple layers of history and geography which extend backwards to the moments in which early humans first sought fish in ponds and streams for food. These layers have then traced the development of human technology and cultural practices, which have sought fish and watery matters first on the shore, then close to it and then out into

\footnotetext{
${ }^{10}$ Habib (2015).

${ }^{11}$ Ibid.

${ }^{12}$ Ireson (2006).

${ }^{13}$ Jung (2018).

${ }^{14}$ Winstanley-Chesters (2016).
} 
the deeper waters of the globe. These practices might have once been described as haphazard, discoveries of the places and journeys of fish and other creatures by chance, often twinned with spiritual and religious rituals to give thanks for the unexpected gift of having located such watery bounty. As technology and industrial capacity developed, however, such practices became ever less haphazard, to the point we have reached now, when fish populations and their routes of travel, migration and breeding can be literally seen from space, through a panoptic technology which allows fishing people to know exactly when and where their quarry is, and how much effort to deploy in order to capture it. Previous chapters have specifically focused on these developments as they have occurred in East Asia, in pre-revolutionary China and in Imperial Japan, and connected them to the geopolitical developments which generated what has been referred throughout this book as an Empire of fishing in the Pacific. The Korean peninsula was of course part of both the Japanese Empire and this Empire of the Sea, and the book has explored the transformation of Korean fishing and coastal spaces from traditional, subsistence to places rooted in the research and developmental prerogatives of the Japanese Imperial project. Later of course, unseen by this book, South Korea developed its industry and technology so that its boats and fishing enterprises would rival Japan and it would become a true master of the global oceans, one of very few nations on earth whose ships can be found in any waters on the planet. ${ }^{15}$ Chapter 4 then considered fishing and the development of maritime resources in North Korea. This chapter traced the history of fishing under the rule of Pyongyang from its emergence as a separate nation in 1948 to the period of stagnation prior to the collapse its communist supporters elsewhere in the globe in the 1980s. In this historical tracing, the connections between industrial practice and ideological development were made clear. North Korea's fishing efforts, like the rest of its developmental practice has been heavily influenced by the ideological needs of those nations which is connected to for support. Thus early in North Korea's history, its fishing policy and practices were heavily influenced by the classical central planning policy of the Soviet Union, and then later following the death of Stalin, when Pyongyang tacked geopolitically towards China, ideas and concepts derived from the Great Leap Forward and the most dramatic forms of Maoist urgency began to influence the nation's developmental strategies. Of course following the obvious disasters of the Maoism's more intense form, North Korea moved to maintain an equidistance between China and the Soviet Union, and thus sought to absorb many of the ideas, practices and technologies developed in the Soviet Union and which had made such a huge difference to its capabilities in the global oceans. This author has tried to give a flavour of this connection in this book using documents which recount the processes and organisation involved from the Soviet perspective of having North Korea integrated into its Pacific/eastern fishing bureaucracies. Chapter 4 sought to give a periodisation of North Korea's fishing efforts and policies, in part led by the frequent writings and assertions of Kim Il Sung on the subject. This periodisation

${ }^{15}$ Anticamara et al. (2011). 
includes an early period which focused on reducing the influence of the Japanese colonial model, followed by a period which sought to increase the scientific and technical capacity of fishing institutions as well as North Korea's boat and ship-building capacities. North Korea then entered into a period, influenced at first by China, which set great goals for production and extraction, goals which on land would seek to transform landscapes and the natural environment, but which at sea sought to transform North Korea itself into a player in the global oceans. The chapter considered the bureaucratic and institutional processes around which all this was framed and gave a sense of some of the key spaces and terrains of North Korea's fishing interest. The reader will have encountered the fishing community, the fishery station and the fishing cooperative in North Korea, as well as the yards of Ryukdae and Chongjin.

In the present, readers of North Korean government reportage and publication will still see on occasion the harbour side and the dry docks of Chongjin, often with an accompanying photo of Kim Jong Un, but will do so with the knowledge that the shipyard has never been able to reach the level of production aspired to by North Korea and that the nation's ships have for the most part remained small, regardless of whatever fishing initiatives had been conceived or developed. North Korea, has the following 2013/2014 returned to fishing and aquaculture as major elements of its developmental strategy given the use of such as a low input, comparatively cheap resource. In spite of the strictures placed upon North Korea's fishing industry by UNSC2397 and other sanctions and restrictions, Pyongyang sees fishing as a viable source of both food and revenue, and it appears has not yet been dissuaded from this by external pressure. Much of the impetus and interest of North Korea in recent years has focused not on familiar fishing communities and villages, but on fishing stations. These are essentially enterprises run by units of North Korea's military, the KPA. Army units are tasked with developing and running fishing stations run on military rules and practices which are vertically integrated, so the KPA supply, build and run the fishing boats. ${ }^{16}$ The KPA repair and maintain the boats and crews and also then prepare and market the product, even researching elements of diversification into other markets. These fisheries stations can focus on classical fishing practice, focused on the deep sea, or they can be on land and focused on aquaculture and fish farming. ${ }^{17}$ An interesting subset of this element has been those stations, which are constructed on the urban rivers of Pyongyang and integrated firmly with state research organisations tasked with further developing an integrated environmental industrial policy and experimenting with whether it is possible to deploy reed beds and fish farms together in order to improve urban water quality. ${ }^{18}$

As readers will have also been aware of, North Korea's approach to fishing strategy and organisation changes quite radically with changes in politics and

\footnotetext{
${ }^{16}$ Bermudez and DuMond (2018).

${ }^{17}$ Ibid.

${ }^{18}$ O'Carroll (2017).
} 
ideology. This is true of other areas of development, for example in agriculture which when North Korea was first organising its approach after 1945 was something of a mixed system, including small private farmers as well as state farms and other collective enterprises. In reality, this was because, even though Pyongyang aspired to be entirely Marxist-Leninist in ideological form, issues with population size and technical capacity meant that it was impossible to hand over all agricultural production to the working class and still maintain levels of production. Thus some private land holding and private enterprise was necessary to keep up supplies of rice and other food. After the Korean War between 1953 and 1956, North Korea was able to reconfigure and redevelop agricultural approach so that it could be undertaken in a more ideologically pure way, primarily through collectivisation and state enterprises. Following the brief dalliance with Maoist urgencies involving enormous numbers of workers from the cities redeployed to work in agricultural settings, North Korea continued for much of the 1970s and 1980s with a collectivist model of agriculture. Finally following the collapse of agricultural capacity in the 1990s, Pyongyang allowed citizens to grow their own food in their home plots, and then to sell produce and materials at what have been called 'guerrilla markets'. This to an extent mitigated the collapse in supply systems and took some of the pressure off the North Korean government and its institutions focused on serving the agricultural needs of its population. ${ }^{19}$ More recently, as I have already suggested in this book, the Korean People's Army has been utilised to reintegrate some of the larger collective farms and new research institutions, such as the Sepho area's enterprises. The KPA, thus, can supply focused and organisation developmental energy, trained and well-fed participants and can market and sell agricultural products both abroad and on the home market, supplying demand, providing hard currency for their products, fees for the rights to do so and reducing some of the burden on the central government budget from the nation's defence needs. ${ }^{20}$

Such a process has been happening for some time at North Korea's coasts and offshore in its waters. Just as in South Korea, historically fishing villages and communities in North Korea have been subsistence based, with a fairly low volume of catch, low wages and constrained economic development. Prior to the 1945 and prior to the Japanese colonial period, North Korea fishing communities would have not ventured far from the shore and certainly not out into the deep sea. They were primarily coastal and inshore enterprises. This was challenged to a degree during the colonial period, though not greatly, as we have seen the Japanese colonial administration was much more concerned to import Japanese fishing people into the Korean peninsula than it was to completely re-engineer Korean's local perceptions of what the industry might be. It was certainly challenged during the chaos of 1945-1948 and then the Korean War period of 1950-1953, when surely a great many fishing people and their families were displaced by the coast. However they cannot all have been displaced, and just as in South Korean territory, some fishing

\footnotetext{
${ }^{19}$ Lankov and Seok-Hyang (2008).

${ }^{20}$ Ibid.
} 
villages and communities survived the war or returned soon afterwards. North Korea sought to initially harness the energies of these communities, interspersed and guided by the various articulations of Kim Il Sung, but also to generate new collective fishing enterprises and to utilise the now centrally organised ship and boat building institutions and yards to supply them with better equipment. North Korea's fishing ministry under the guidance of Kim Il Sung and wider policy framework sought to organise much of the fishing in the 1960s through these large collective enterprises, but often the best fishing on the peninsula is done on peripheral spaces, far from areas which might be useful for extensive production and infrastructure building. In the 1970s, this sense that the most effective places for fishing in the country might be at its most peripheral places, was twinned with projects which focused on the rehabilitation of unusable land or the reclaiming of coastal land from the sea. These projects focused on a cooperative model, sourcing families and fishing people from a variety of other communities along North Korea's coast and forging them into smaller cooperative units. These cooperative units for a moment in North Korea's fishing history were vital to its developmental approach, focusing not just on fishing and the extraction of product from the sea, but also the reorganisation of family and social groups at the state's behest, and on the reclamation and creation of new useful land from the sea, a hugely important task given North Korea's political ambitions a real way of creating new socialist territory over which Pyongyang could rule. One such cooperative site was at Sindo, a small island in the mouth of Amnok/Yalu (압록강/鸭绿江) River and the newest county in North Korea.

Sindo has long been of interest to the author of this book. For some time before I became interested in the watery and fishy matters of North Korea, I had been focusing on developmental communities in the nation, specifically those that worked in the forestry and timber sector and those that sought to reclaim land from the sea. For the most part, such communities were present in the spaces they worked in for only short periods, completing one project, or being tasked with something before moving on to the next engagement or the next task. Often the places and spaces they lived in during their periods of engagement were deliberately built for the purpose of undertaking that engagement. They had tenuous, short-term links to the geographies and terrains they sought to transform and were for the most part either epistemic or technical communities, rooted in research, academic work or developmental effort. Previous fieldwork I had undertaken in North Korea had been focused on just these sorts of communities and had felt primarily like engaging with groups of researchers similar in a way to me. ${ }^{21}$ While these communities and similar engagements are considered rare by popular or public narratives, in reality they are not. North Korean researchers, technicians and developmental specialists have been making connections with similarly minded academics communities across the globe for many, many decades now. This book has even recounted some of the moments in which North Korean fishery specialists

\footnotetext{
${ }^{21}$ Winstanley-Chesters (2014).
} 
sought to make connections with the Soviet Union in the 1970s and we know that developmental specialists from all fields from North Korea were embedded in a variety of projects across the globe during the period of communist and socialist solidarity. Following the famine period of the early 1990s, North Korean technical and research communities met and engaged with a number of external partners to support Pyongyang's recovery from that difficult period. In more contemporary times all manner of foreign researchers and projects have engaged North Korean academics, specialists and other technical workers, from Volcanologists, health researchers, and Computer Scientists to bureaucrats and specialists in renewable energy. ${ }^{22}$ Yet, North Korea is famous for restricting the connections between foreign visitors of most types and its regular, non-specialist citizenry. It has historically been almost impossible for foreigners of any type or situation to engage with normal people in North Korea, though this has begun to change in recent years with a slightly more relaxed attitude on occasions and even cases of comfortable friendly interaction on university campuses and elsewhere between locals and visitors (though this unfortunate case resulted in the eventual detention and deportation of the foreigner involved, shortly before the manuscript of this book was finalised). ${ }^{23}$ Historically, this extreme difficulty in connecting with local North Koreans even meant that developmental spaces and their communities could seem amorphous, abstract and unreal. Whatever lively and energetic matters there might be, certainly appeared out of reach to the visitor. Such places appeared to be almost entirely unknowable.

Sindo, however, appearing in the Works of Kim Il Sung in the early 1970s, perhaps could have been different. A single developmental community on a patch of land that was fairly small and absolutely trackable via Google Maps and other GIS techniques (and more conventional and old fashioned tools of surveillance such as those found in NARA's collection of aerial photography held at College Park, Maryland), as well as easily defined temporally could be different. Perhaps this community, engaged as it has been, in a developmental project which is not, by North Korean standards hugely controversial or politically embarrassing, could be reached, perhaps its energies and vibrancy could be known. It might be possible in our contemporary times of increased openness from North Korea to really know one of its developmental communities. Hence, the author of this book started this project, which for a time became enmeshed in the work of Tessa Morris-Suzuki at Australian National University focused on what she had called 'informal life politics'. ${ }^{24}$ In North Korea, one would require both an extensive repertoire of very formal life politics as well as anything informal, but the practicalities of engaging with little resource and very challenged capacity with the denuded seas of the world in a time of acute environmental crisis would surely require a great deal of flexibility and skill. While such a theoretical frame has become less important as time as

\footnotetext{
${ }^{22}$ MacDonald (2016).

${ }^{23}$ Sigley (2019).

${ }^{24}$ Morris-Suzuki and Jeong Soh (2017).
} 
gone on in the writing of this book, the reflexivity of those involved and of North Korea, in general, is powerful in the author's thinking. It might not surprise the reader to learn that while a great deal of watching, considering, knowing has gone on so far as this community is concerned, so far as actual engagement and meeting is concerned that has been a different matter.

As I have iterated elsewhere in this book and in this chapter, North Korea's new fishing initiatives in the 1970s and the fishing bases mentioned by Kim Il Sung on the West Sea coast were not isolated and disconnected from other national developmental imperatives and agendas. Projects which focused on coastal reclamation and land rehabilitation had followed a similar institutional journey to those, which focused on fishing since the 1950s and had been re-conceptualised in the 1970s within a new developmental framework of organised goal setting and increased capacity. This increased capacity would come in part from technological change and imagined efficiencies, but also from literally creating new land. Sindo Island itself was one such piece of terrain reconfigured and generated by North Korea's utopian urges to generate new Socialist land which could support increased capacity.

Sindo island was forged from the estuarial bed of the Amnok/Yalu River, downstream from Sinuiju/Dandong initially in 1958. As part of a wider drive for land reclamation and capacity increase during the 1970s and what was known in North Korean government narratives as the 'era of 300,000 ha', the small island and sand banks on opposite side of the Yalu boundary with China were reclaimed to form Sindo Island and reconfigured later in 1991 into a new county. ${ }^{25}$ A fishing cooperative was formed on Sindo's reclaimed land from communities elsewhere on the coast, during the era of fishing cooperative development outlined elsewhere in this book. Sindo's cooperative was even visited by Kim Il Sung in 1976. In the years following the deaths of Kim Il Sung, Kim Jong Il and the difficulties of the crisis period in the mid-1990s Sindo completely slipped off Pyongyang's developmental radar becoming an even more marginal, half-remembered site. ${ }^{26}$ While fishing and maritime activity is certainly still a feature of North Korean government policy, as evidenced by the many appearances of Kim Jong Un in 2015 at various coastal installations, Pyongyang, like as is the case in other developmental utilises the KPA as the primary agent of its functionality and driver of institutional change. Yet in spite of the KPA's dominance, the resident community at Sindo Island would have to continue their lives and work focused on fishing and would occasionally be referenced by North Korea in its historical narratology.

The story of Sindo, therefore, is in a sense a similar narrative to those of other developmental projects in North Korea as the nation entered the difficult period following the collapse of the Soviet Union and Warsaw Pact. The story of Sindo and other North Korean fishing communities and enterprises, for example, mirrors that of the tideland reclamation sector. The reclaiming of coastal land by local and

\footnotetext{
${ }^{25}$ Winstanley-Chesters (2016).

${ }^{26}$ Ibid.
} 
regional bureaucratic institutions and by local communities had long been part of North Korea's developmental strategy. Coastal land engineering and reclamation had been a key part of the dramatic projects aiming for a complete transformation of nature and of the various planning periods of North Korea's commitment to central planning. North Korea's 'Third Seven-Year Plan', which included extensive elements of coastal reclamation and reconfiguration proved very short lived and developmental policy was rapidly overtaken by the consequences for North Korea of the collapse of the Warsaw Pact and the USSR between 1989 and 1991. North Korea, its development and those communities undertaking it were forced to take a new direction, disregarding any previous ideological agendas or progression.

Given the collapse of much of North Korea's bureaucracy, the difficulties with finance and the disappearance of eternal partners, progress by both the state and developmental communities focused on hydrological projects during this period of disruption, might have been expected to have been limited. However, documentation from the KCNA and American sources suggests that work on key tideland reclamation projects, including Taegyedo, was sustained to a surprising extent. ${ }^{27}$ This continued work provides evidence of pragmatic shifts in developmental strategy, shifts in strategy which would go on to diminish the role of local bureaucracies and communities in favour of the remaining, functional military institutions and bureaucracies. During August 1992, for example, it was reported from the Kumsong tideland reclamation area in Hamgyong province that 'soldier builders have laid a dam extending more than $1,400 \mathrm{~m}$ in the last two months to complete the first damming project by introducing advanced construction methods' ${ }^{28}$ This project was soon finished with the KCNA reporting a year later that ' 3,300 ha [had been] reclaimed, as part of the wider project for the reclamation of 300,000 ha, including 110,000 in North Pyongan, 110,000 in South Pyongan and 80,000 ha in South Hwangae' ${ }^{29}$ Further work by the military was also undertaken in 1995 within North Pyongan province, in areas surrounding the Taegyedo project, and there were reports of a new barrage at Cholsan being constructed. Rodong Simnun $^{30}$ reported that this barrage 'makes it possible to water 6,000 ha of reclaimed tideland'. Responsibility at this point as this chapter has already pointed out, for major reclamation projects shifted from local and provincial institutions. The KPA is described in contemporary reports as the initiator and planner of such projects, reflecting a radical change of policy and approach. Whilst the KPA had undoubtedly provided support for local projects, North Korea's military forces had not previously assumed direct responsibility for projects which developed industrial, technological, agricultural or hydrological capacity. This shift formed part of Pyongyang's new 'military first' or 'Songun Politics', which subsequently

\footnotetext{
${ }^{27}$ Ibid.

${ }^{28}$ KCNA (1992).

${ }^{29}$ KCNA (1993).

${ }^{30}$ Rodong Sinmun (1995).
} 
incorporated into most elements of practical policy in North Korea. ${ }^{31}$ Taegyedo Tideland Reclamation Area. A project which was originally undertaken by its local communities to serve their local agricultural and developmental needs was thus completed by the military who gained much of the prestige and funding connected to it and whose completion was used during the Kim Jong Il era to reflect the political charisma of the leadership on the newly created landscape. These developmental communities and local bureaucracies in common with many other sectors of North Korea's economy were swept aside in the era of the second arduous march, their importance diminished and their stake in development and economics challenged.

The disappearance of coherent local bureaucracies and state power within this developmental sector and the peripheral spaces of governmentality while, on one hand, demanded the interjection of military capacity, it can also be seen as connecting to some of the more extraordinary and unexpected results from the difficult and 'arduous' period under Kim Jong Il, which can in a sense really be conceptualised within the frame of 'informal life politics'. The failure of Pyongyang's bureaucracies to provide for its peripheral populations and communities after 1992 through past infrastructures such as the Public Distribution System meant that people had to adopt other strategies to guarantee their survival. ${ }^{32}$ While many citizens of North Korea did not of course do this, and still others adopted a strategy of mobility which saw them escape the bounds of Pyongyang's sovereignty becoming refugees or economic migrants elsewhere in East Asia and the world, the majority engaged with processes of informal marketization in order to secure goods and sustenance. The Guerrilla Markets sprung up throughout North Korea as physical manifestation of grassroots practices and processes of capitalism and private enterprise which could be conceptualised as spaces in which digression from ideological purity or hegemony could be accomplished, generating new landscapes of the market. ${ }^{33}$ Sindo and its fishing community in common with the community around Taegyedo, also on the West Sea coast of North Korea were also subjected to the processes of diminution which produced new spaces of marketisation and exchange elsewhere in North Korea.

For Sindo and its community at the North Korea's northern border, however, the path of development and possibility provided by the collapse of institutional authorities could not run smooth. What happened between 1976 and the present at Sindo is extremely hard to say, and certainly in the processes of research through which this book was formed, little concrete has been found. The physical geography of Sindo, including its major island Pidansom (비단섬), changed little between the 1970s and the 1990s, viewing the island through the aerial reconnaissance archive held by NARA showed the island being knitted together in its present form through reclamation from the late 1950s to the early 1970s. By 1971/

\footnotetext{
${ }^{31}$ Park (2007).

${ }^{32}$ Noland (1997).

${ }^{33}$ Smith (2009).
} 
1972, the island appears to have reached its greatest extent, merging together a number of smaller islands and small settlements, dock infrastructure and tracks across it become visible. Much really stays the same for the next couple of decades, Pidansom is drained a little further than it had been initially, and perhaps a little more development takes place along its north coast, however, it is for many years until to the north of Pidansom, an area of the estuary to the north of the main river flow is drained extensively, rather incongruously creating a piece of North Korea on the northern side of the Amnok/Yalu River. This has become known as Hwangkumpyong (Hwanggeumpyeong) (황금평) and in our present is extremely close to one of the main roads leading out of Dandong as well as Chinese railway lines to the north of the river. Both North Korea and China sought to develop the area as a Special Economic Zone following the 2000s though it appears from satellite photography that very little happened. ${ }^{34}$ By 2011, it was revealed as the Hwangkumpyong SEZ and a variety of publicity material and billboards put up on site, as well as public announcements made focusing on how important it would be and how much trade and business was going to pass between North Korea and China as a result of it. ${ }^{35}$ Andray Abrahamian of Chosen Exchange and Theo Clement were two of many visitors to the area in the years following its unveiling, however, by 2013 and 2014, it was clear that virtually nothing had been built on the site since $2011 .^{36}$ In fact, the execution of Jang Sung-taek in 2013 broke many of the institutional connections, which had been leveraged to make the project happen in the first place and without them Hwangkumpyong appeared destined for non-completion for many years in the future.

The rest of the Sindo County area and the island of Pidansom remained without any further development until the turn of the 2000s. At this point, at least two further installations were construction on the islands west coast, facing the sea with what looked like the beginnings of aquacultural development. Over the preceding decades, Pidansom had also been further drained and agricultural developments are clearly outlined on the maps and on satellite imagery from the area. The original fishing cooperative occupied a coastal area at the most southerly tip of the island, below a small village named Chogumsa, which while small clearly has its Party foundation monument and parade ground. It is unclear whether this village, or in fact this part of the island received anything in the way of support or materials for many decades following its moment of interest in the 1970s. The author of this book was very concerned for many years to physically visit the island, and came closest to organising a trip around the year 2016. In this year, I was supported by the research project, which I was part of at Australian National University to visit a number of the fishing communities discussed in this book and to arrange a visit to North Korea, specifically to engage with fishing projects and initiatives there. If any reader has experience of arranging fieldwork to North Korea, they will surely know

\footnotetext{
${ }^{34} 38$ North (2012).

${ }^{35} \mathrm{Ibid}$.

${ }^{36}$ Choson Exchange (2014) and Theo Clement (2016).
} 
the process making such arrangements and the intriguing complications that can be found along the way. Suffice to say, it is fairly easy, unless you are an American citizen (who cannot as of 2019 visit North Korea without a reason satisfactory to the current administration, surrendering their passport to the State Department and having a special one use only travel documents issued), to visit North Korea to spend several weeks being shown the monumental architecture of Pyongyang and a large number of pictures of Kim Il Sung and Kim Jong Il. It is less easy to visit North Korea and do actual empirical work, to collect functional and viable data and to engage with a real research community or object. Even if you do manage to arrange a visit to do such things, your intricately, politely and carefully developed plans can be subject to change at the last moment and in a way which cannot be appealed against (there are few appeals in North Korea of course). On previous occasions in which I have done fieldwork in North Korea focusing on developmental projects, changes occurred which actually benefited my interests and were extremely generous on the part of local institutions. I was able to visit places I had never imagined visiting and to see things I had not heard any researchers engage with before. I have seen similar moments happen to colleagues in the field of geography, but also volcanologists, architects and health practitioners. On this occasion it did not happen to me, primarily because of the vagaries of ethics committees within Australian institutions, but also because Sindo was too hard a place for local institutions to consider me visiting. It was quite possible to visit the shipyards of Chongjin, quite possible for me to visit port facilities at Nampo and elsewhere (though not necessarily from the shore), but it was problematic for me to physically visit Sindo itself, or the fishing cooperative just south of Chogumsa.

Unlike the busy community at Gageodo or the small fishing villages of Liaodong, including Tong Shui Gou and Jinshitan, beset by both economic and environmental pressure, this book would have to consider Sindo and its fishing cooperative mainly from afar, but with an academic gaze rooted in fieldwork done in neighbouring fishing spaces, history and an awareness born out of knowledge of environmental and other data. It is worth remembering that Sindo itself, as an island would dramatically impact upon the flows and hydrology of not just the Amnok/ Yalu estuary, but also the waters around it. The river has also been a source of great amounts of silt, and deforestation that has occurred from many centuries ago would have certainly impacted on the amount of material entering the river. While this area of North Korea has not been extensively farmed, the collapse in local irrigation and agricultural systems following 1992 cannot but have increased the amount of material eroded from the hillsides and mountains still further. Across the world as climate change has developed and increased temperatures have dried out the landscapes at higher altitude and altered ecosystems there, much soil, sediment and peat material has been lost, flowing downhill into streams and rivers as sand and other fine materials (this is certainly true in the areas near to where the author of this book lives). ${ }^{37}$ This will have impacted greatly on the flow of the Amnok/Yalu and

\footnotetext{
${ }^{37}$ Harrison et al. (2008).
} 
on those species of fish which inhabit the river, as well those species which inhabit the areas of the sea just offshore. Sea level rise will also be impacting on the tidal range of the river, as again will the physical geography of the island itself, and the extension on which Hwangkumpyong SEZ perhaps one day will be built.

Sindo fishing communities will also be challenged by a huge drop off in the volume of fish and other marine life in the waters in the East Sea/Yellow Sea. This area is one of the many across the globe which has begun to produce either permanent or seasonal dead zones, anoxic, as in oxygen-free or depleted areas of water in which little can live. ${ }^{38}$ Often such the zones are product of extensive agricultural run-off into river systems, containing as it often does in industrialised agriculture, very high levels of nitrogen and other organophosphates due to heavy levels of fertiliser use on the land. ${ }^{39}$ Urban areas, especially those built in a hurry and without functional or responsible urban planning, can also discharge enormous volumes of human and other wastes directly into the sea through either sewage systems designed to do just that, or sewage systems which have become overwhelmed by the size of contemporary populations or increased rainfall events which have become much more frequent in an age of climate change. ${ }^{40}$ Many of the shallow waters along China's coast have been shown to develop extreme levels of Hypoxia and Eutrophic events such as vast blooms of green algae have become more and more frequent along its shores. ${ }^{41}$ While South Korea has partnered China, Japan and the Russian Federation recently in detailing some of the instances of such impactful and widescale events in their seas and coasts, North Korea has as of yet not done so. This does not mean that North Korea's coastal and shallow water areas would not be impacted by such processes and events. The collapse in the use of chemical fertiliser in North Korean agriculture and the decline in the nation's industrial base removed some of the primary causes of such environmental issues. However, the importance of North Korean urban centres and a lack of availability of finance to support the maintenance of sewage and waste disposal facilities, coupled with the increasing number of heavy rainfall events brought by a changing climate mean that the nation's fishing communities are very likely to face similar spaces along its coast. If North Korean fishing communities such as Sindo are not faced with Anoxic or Eutrophic spaces directly on their own coast line, then surely when fishing in the West Sea/Yellow Sea or in Korea Bay, which the Amnok/Yalu River feeds into they will encounter them.

Fishers from Sindo would be faced with many of the same fishing resource problems as those the author of the book found were faced by communities on the Liaodong Peninsula. These anoxic, Eutrophic and pollution events have really impacted heavily on the volume of fish available in the areas that they would fish. It is quite evident that for the most part North Korea's fishing communities do not venture far, there are simply not enough large boats in the country for extensive

\footnotetext{
${ }^{38}$ Diaz and Rosenberg (2008).

${ }^{39}$ Townsend and Howarth (2010).

${ }^{40}$ Chen et al. (2007).

${ }^{41}$ Zhou et al. (2001).
} 
fishing efforts in the deep sea. The virtual absence of North Korean boats from the deep Pacific as recorded by the North Pacific Fisheries Commission and West and Central Pacific Fisheries Commission reports in the present day and the fact that those boats from North Korea that are known about catch only a very small tonnage of fish in comparison to other nations in the area, further suggest that communities such as Sindo will struggle in any effort to extract great volumes from the sea. While elsewhere on the globe, seafaring communities challenged by similar issues have been beset by extensive numbers of invasive species (European Green Crabs, for instance, which have become prevalent in Canadian waters and which have begun to severely impact local ecosystems), in the water, the ecological restrictions placed on the waters of Northeast Asia have meant that, in fact, the primary invasive marine species is a species of Cord Grass Spartina alterniflora which impacts coastal tidal flats, severely reducing their biodiversity. ${ }^{42}$ Korea Bay and the West Sea/Yellow Sea are so degraded ecologically that the marine ecosystem is not inviting to invasive or new species and its more regular inhabitants are in serious decline. Recent scientific analysis, for instance, shows that mollusc species which are vital for shore economies have declined precipitously in biodiversity from hundreds of species present to seven, and that even the Chinese Shrimp which is a hugely important species for fishing communities has declined in population so far as to now be classed as endangered. ${ }^{43}$ The degradation of shrimp populations was all too obvious during fieldwork by the author of this book at Tong Shui Gou.

Beyond the core issues of climate change, sea level rise and environmental degradation and reduced biodiversity which would challenge any coastal community, the fishers of Sindo and other nearby North Korean communities have long been further challenged by the fact that the mouth of the Yalu has long been problematic in the relationship between China and North Korea. Pidansom one of the islands that now forms part of Sindo was actually once Chinese territory (known as Chouduandao 綢緞島), inhabited by a number of Chinese fishing families, but had fallen under Korean control around the period of Japanese colonisation. North Korea had offered after the 1950-1953 war to return the island to China as a gift for the support given by the Chinese volunteers, but had in fact never done so. ${ }^{44}$ The developmental dreams of North Korea which resulted in the entire area becoming one single island, Sindo in the late 1960s and early 1970s meant that the People's Republic of China had to evacuate those Chinese families from Chouduandao in 1969. This is in spite of the fact that in 1949, at the conclusion of the Chinese Civil War, both China and North Korea had agreed to manage the area of the Amnok/ Yalu River mouth jointly together, not demarcating the international boundary down the midstream of the river as is conventional in most other territorial examples. $^{45}$ North Korean actions over many years, including the co-opting of the

\footnotetext{
${ }^{42}$ Wang et al. (2006).

${ }^{43}$ UNEP Regional Seas (2011).

${ }^{44}$ Pinilla (2004).

${ }^{45} \mathrm{Ibid}$.
} 
entire territory of Sindo have gone against the spirit of this conclusion. North Korea in 1977 even followed the practice of seafaring nations across the world seen in an earlier chapter of this book and extended its economic exclusion zone to some 200 miles, an extension which proves highly problematic in such a space as the mouth of the Amnok/Yalu. ${ }^{46}$

In more recent years, however, it has not been North Korea's complicated engagement with the territorial boundary arrangements between itself and China that has been the primary problem for the fishers of Sindo and other North Korean fishing communities along its coast. The environmental issues outlined earlier in this chapter have meant that the West Sea/Yellow Sea and the areas of the Bohai Sea just to the west of North Korea have become extremely depleted of fish, as well as ecologically degraded and polluted. China has, in fact, closed most of the area above the 35th parallel to all fishing boats in the summer months since the year 2004. North Korea itself in recent years has also sold what little there remains in its West Sea EEZ to Chinese fishing enterprises for hard currency, so that North Korea's larger boats have to sail further afield. ${ }^{47}$ These larger North Korean boats themselves have issues of range and capability and cannot themselves travel or fish very far away from the home ports. There have been a number of instances of North Korean boats illegally fishing for squid at night in the Japanese EEZ because of this. ${ }^{48}$ All of these environmental issues and border issues pale into comparison with the more recent fact of UNSC2371, the sanctions regime which, in fact, makes it illegal for North Korea to sell any seafood or maritime product to anyone and also makes it illegal for any other country to buy such products. ${ }^{49}$ UNSC2397 explicitly outlaws North Korea from selling any of its own rights to other countries and seeking value and funding that way from the sea. ${ }^{50}$ This has further problematised much of the interest detailed by Bo Gao, from Chinese fishing enterprises following both the restriction of other waters to Chinese boats and the unfortunate radioactive pollution of their preferred grounds in the North Pacific following the Fukushima Incident in Japan in 2011. ${ }^{51}$ All this has further complicated the fishing market for North Korea, even at those moments with, for example, Chinese enterprises who are most malleable when it comes to international law and the restrictions it places on North Korean fishers.

Small fishers from communities like Sindo are therefore caught in many binds, not simply environmental, but also governmental, institutional and legal, which restrict their capacity and the sea space from which they can extract fish and make a living. It is also worth reminding the reader that when it comes to institutional support within North Korea, such communities are now at the absolute bottom of

\footnotetext{
${ }^{46}$ Ibid.

${ }^{47}$ Shim (2016).

${ }^{48}$ Princic (2018).

${ }^{49}$ United Nations (2017a).

${ }^{50}$ United Nations (2017b).

${ }^{51}$ Gao (2019).
} 
the pile when it comes to governmental interest. As North Korea's KPA now controls the vast majority of the nation's boats, fishing rights and production/ preparation facilities, the small boats of fishing cooperatives and other subsistence communities are very low in the list of priorities for local institutions. If there is fishing to be done, primarily it will be done by fishers of the KPA rather than places like Sindo.

North Koreans, however are resilient and always capable of finding their way around a seemingly intractable problem, so it would not surprise the author of this book if fishing communities like Sindo, or perhaps even Sindo themselves found a way of extracting value from their denuded sea and in some way continued to make a living, regardless of the multiple challenges facing them. The current institutional interest shown in not only more generally the fishing sector, but very specifically the island of Sindo the reclaimed land surrounding it, speaks to this fact. Sindo is famous not only for its fishing and fishing station, but also for its reed beds, and perhaps some of the focus recently bestowed on these spaces by the visit of Kim Jong Un would flow to the community nearby.

So in this chapter and in this book, readers will have come close to the fishing people in Sindo, close to the small fleet of boats moored off the tip of the island and the collection of buildings which service them next to the coast. They are, as is often the case in North Korea, tantalisingly out of reach from both myself as the researcher, and us as the readers of this book. While North Korea's interest in the lively matters of this island continues to grow, the benefit for these fishers declines, just as the population of fish in the nearby waters of the Amnok/Yalu River and the Yellow and Bohai seas decline. However, as is often the case again in North Korea in contradiction with these declines has been the rise in interest within Pyongyang's narrative in fishing and watery matters.

Chapter 4, this books' concerted effort to extract a historiographic narrative and sense of geography from the strands of North Korean political messaging and elements of the often hidden documentary evidence of Pyongyang's intentions and efforts at sea, has detailed the outburst in 2014 of institutional interest which detailed the reconfiguration of its strategies for fishing away from places and communities like the Sindo cooperative and towards the various infrastructures of the KPA. That chapter, for the most part, focused on the events and focus of 2014 and 2015, the era of 'mountains and seas of gold'. From the intense peak in the middle of the decade, institutional interest seemed to have waned a little in 2016 when Kim Jong Un in his New Years Address could only muster the direction: 'fishing sectors...should ramp up production as soon as possible and see to it that the fish farms...built across the country pay off... ${ }^{52}$ But North Korea certainly paid attention to fish farming and aquaculture in 2016, with a number of media and government announcements of new projects in Pyongyang and elsewhere. This was, of course, the peak period for the Byungjin Line (병진로선), North Korea's developmental and ideological strategy which paired technical development in the

\footnotetext{
${ }^{52}$ Rodong Sinmun (2016).
} 
economy with nuclear capability and capacity. Fishing and watery matters it seems could certainly play their part in the drive to increase the technical capabilities and level of North Korea's various developmental sectors. As readers will know this increasing focus on nuclear capability drove international focus on North Korea to something of a fever pitch, and Pyongyang and Washington DC after a few too many early morning missile launches with Kim Jong Un in attendance seemed at points destined for a real military confrontation. ${ }^{53}$ Amidst the heat of it all, North Korea still included fishing policy in its developmental agenda. 2017's New Years Address, for instance, reminded readers of the difficulties North Korea has had historically with increasing the size of its fishing boats and developing their capabilities: 'The fishing sector should conduct a dynamic drive for catching fishes and push perseveringly ahead with aquatic farming... It should build modern fishing vessels in a greater number..., 54

2018 was a unique year in North Korean political history. In the middle of the disturbing geopolitical volleys between North Korea and the United States, Moon Jae-in had been elected as President in South Korea on a platform which included some form of return to his political mentor Kim Dae-jung's 'Sunshine Policy'. At a speech in Berlin on 6 July 2017, the new President Moon made it very clear he was minded to overturn some twenty years of conservative party policy on North Korea if given the chance. Rüdiger Frank of the University of Vienna recorded the core intentions in the speech as '... Moon repeatedly expressed his willingness to respect and accept North Korea as it is. To make sure the message isn't missed, he explicitly said that he neither wishes for North Korea to collapse nor that he will work towards any kind of unification through absorption...' 55 Given the bluster coming from Washington DC it never looked as if Moon would get the chance, but the Pyeongchang Winter Olympics in the early months of 2018 provided an opening that perhaps no one saw coming. It appears that mindful of Moon Jae-in's inclinations, Kim Jong Un's New Years Address of 2018 included the hope that North Korea and South Korea might cooperate in some way during the period of the Winter Olympics, as they had done at previous international sporting events. Seoul and the Moon administration acted within $48 \mathrm{~h}$ of the address being posted and by the 9 January, both sides were discussing the possibility and within a month North and South Korean athletes were participating with a joint team at the Winter Olympics. ${ }^{56}$ While the attendance of Kim Yo Jong, Kim Jong Un's sister and Kim Yong Nam (North Korea's then official head of state, Chair of the Praesidium of the Supreme People's Assembly) at the opening ceremony and their handshakes with the South Korean President would have been absolutely extraordinary in normal times. However

\footnotetext{
53“North Korea Confirms Successful New Ballistic Missile Test," BBC News, May 21st, 2017. Retrieved April 27, 2019 https://www.bbc.co.uk/news/world-asia-39990836.

${ }^{54}$ Rodong Sinmun (2017).

${ }^{55}$ Frank (2017).

56“"North Korea Accepts Olympics Talks Offer says South,” BBC News, January 5th, 2018. Retrieved April 77, 2019 from https://www.bbc.co.uk/news/world-asia-42574870.
} 
within months, Moon Jae-in and Kim Jong Un met at Panmunjom and signed the April 27th, Panmunjom Declaration, the first of three search meetings and by June, Kim Jong Un and a North Korean delegation were meeting US President Donald Trump at an extraordinary event in Singapore (so far the first of three meetings between the two men, and certainly the most substantive and successful). ${ }^{57}$

Not only in 2018 had North Korea avoided the seemingly inevitable (in 2017 at least) attack from the United States and its allies, but as a nation, it had rather punched above and beyond its weight and reputation on the global stage, in spite of the various sanctions regimes and processes. While 2016 and 2017 had brought severe restrictions on its developmental output through the UNSC 2397 and unilateral sanctions put in place by the United States through Edward Royce's HR757 Bill, perhaps a way forward could now be found for the future. ${ }^{58}$ Fish and fishing would it seems certainly play a role in whatever future that would turn out to be. While the Winter Olympics in Pyeongchang were happening, North Korea's long-standing joint commission on fisheries with the Russian Federation (this book has explored moments of interaction produced as a result of this commissions' previous iteration with the Soviet Union as a partner), took place for the thirtieth time. Interest remained high in fishing matters throughout the year and Pak Pong Ju, then Premier of North Korea would be seen in government publications visiting fish farms, a railway bridge and a new railway line built to connect new fishing facilities on the Songjon peninsula near Wonsan and the opening of a new 'National Fish Breeding Laboratory'. Kim Jong Un himself made time in 2018 to visit salmon farms, the Samchon Catfish Farm and a number of the KPA's Fishery Stations. ${ }^{59}$ For this book and its author however the most important moment in North Korea's developmental year in 2018, was Kim Jong Un's visit to Sindo itself. Rodong Sinmun records that on 30 June 2018, Kim Jong Un paid a visit along with a number of other officials as part of a more extensive visit to Sinuiju and the northwest corner of North Korea to the islands. ${ }^{60}$ Such a visit does inevitably put greater institutional focus on this once forgotten place, even with the dreams and ambitions of Hwanggumpyong SEZ to its north. But it was not focused on the island and the various communities of fishing people who live there that was important on this occasion to North Korea. Granted fish and fishing in 2018 were lively matters among many others for North Korean institutions, but it appeared that another form of vibrant material was the key concern. Kim Jong Un was in fact visiting 'Reed Branch Farm 1' of the Sindo County Combined Reed Farm (the text from Rodong Sinmun asserts that this farm was also visited by Kim Il Sung and Kim Jong Il), in order to see developments in the production of reeds for the fibre and chemicals industry. ${ }^{61}$ This natural product has become important to North

\footnotetext{
${ }^{57}$ Lyons et al. (2018).

${ }^{58}$ United States Congress (2016).

${ }^{59}$ Rodong Sinmun (2018a, b, c, d, e).

${ }^{60}$ Rodong Sinmun (2018f).

${ }^{61}$ Ibid.
} 
Korea since it can no longer afford or source fibres produced through chemical process or based on petroleum by-products. Sindo thus in North Korea's institutional mind, in 2018 is not a place for the fishing cooperative and fishing interests (though fishing does have a brief mention in the text recounting the visit), but for other forms of material, other lively energies in the matrix of the nation's development.

\subsection{Conclusion}

Sindo is one of those terrains in North Korea that certainly can be seen and studied from space. GPS-enabled satellite photography can show the reader and the watcher the outline of its fishing facilities, the monument at the heart of its main village square, the developments on its west coast and increasingly the turpidity and sediment build up in the Amnok/Yalu estuary. The post-imperial technological gaze can show the interested and the curious all of these things, but it cannot get anyone close to the reality of the small fishing community on its southern tip and their politics and political strategies, informal or otherwise. Sindo has long been caught in web of environmental crisis, developmental stasis, geopolitical complication and institutional disinterest, and all of these do not make the community there itself anymore visible or any more reachable. It is a fundamental disappointment to the author of this book, that the space and place they had set out to engage with have on this occasion been essentially and practically unreachable. I hope that this does not make this book without merit. It has been a long journey intellectually and conceptually to this point, and on that journey, I hope that vibrant and lively fishing matters, or the place of such matters in North Korean political and developmental practice has become a little less opaque.

The final concluding chapter of this book seeks, not just to summarise and reiterate the various temporal, geographic and conceptual scales and frames the reader will have gone through to get to this point, but to open out the frame once again. At this point, the reader and the narrative of this book have arrived in 2019 at a small community, a little beyond physical reach, at the mouth of the Amnok/Yalu River. While for many analysts, readers and writers, such a place is out of time, out of political space, out of the social, economic and ecological frame that much of the rest of the globe sits in, it has throughout this book and throughout the research and fieldwork that is behind the words of this book, always been the ambition of the author to put Sindo and watery geographies like it back into the framework of political, economic, social and environmental time. North Korea is part of a peninsula, it is not an island or a satellite of the wider world, circling it forever like an unusual aberration. As a nation is as much a part of our global neighbourhood as any other place, its own environmental crises are simply offshoots of the wider planetary crisis that is befalling us all as a result of unfettered growth politics and an industrial and economic system predicated on and defined on their being no limits. Non-human materials and energies have been harvested and extracted from our 
world to the extent that the lively and powerful matters on which humans as a species have depended on for so long are now depleted beyond repair, or present in such a great volume that we are on the brink of a radical transformation in our ecosystem. This book has so far very much attempted to tell this narrative, and Sindo, however, accessible is certainly part of that story.

\section{References}

Anticamara, J.A., R. Watson, A. Gelchu, and D. Pauly. 2011. Global Fishing Effort (1950-2010): Trends, Gaps, and Implications. Fisheries Research 107 (1-3): 131-136.

Bermudez, Joseph and DuMond, Marie. 2018. North Korean Strategic Fisheries Development Persists in Spite of Sanctions. Beyond Parallel, September 19th, 2018. https://beyondparallel. csis.org/modernization-expansion-project-korean-peoples-army-fishery-station-no-15/. Accessed 27 Apr 2019.

Boffey, Daniel. 2019. UN Calls for Food AID for Starving North Koreans Despite Sanctions, The Guardian, April 3rd, 2019. https://www.theguardian.com/world/2019/apr/03/un-calls-onwhite-house-to-aid-north-korea-despite-standoff. Accessed 27 Apr 2019.

Chen, Chung-Chi, Gwo-Ching Gong, and Fuh-Kwo Shiah. 2007. Hypoxia in the East China Sea: One of the Largest Coastal Low-Oxygen Areas in the World. Marine Environmental Research 64 (4): 399-408.

Choson Exchange. 2014. Hwanggumpyongs Master Plan. Choson Exchange, August 12th, 2014. https://www.chosonexchange.org/our-blog/2014/7/29/hwanggumpyongs-master-plan. Accessed 27 Apr 2019.

Diaz, Robert, and Rosenberg, Rutger. 2008. Spreading Dead Zones and Consequences for Marine Ecosystems. Science 321 (5891): 926-929.

Frank, Rüdiger. 2017. President Moon's North Korea Strategy. The Diplomat (original version 38 North), July 13th, 2017. https://thediplomat.com/2017/07/president-moons-north-koreastrategy/. Accessed 27 Apr 2019.

Gao, Bo. 2019. China's Economic Engagement in North Korea. Singapore: Palgrave Macmillan.

Habib, Benjamin. 2015. Balance of Incentives: Why North Korea Interacts with the UN Framework Convention on Climate Change. Pacific Affairs 88 (1): 75-97.

Harrison, Anthony, et al. 2008. Potential Effects of Climate Change on DOC Release from Three Different Soil Types on the Northern Pennines UK: Examination Using Field Manipulation Experiments. Global Change Biology 14 (3): 687-702.

Ireson, Randall. 2006. Food security in North Korea: Designing realistic possibilities. The Walter H. Shorenstein Asia-Pacific Research Center. https://fsi-live.s3.us-west-1.amazonaws. com/s3fs-public/evnts/media/Ireson_FoodSecurity_2006.pdf. Accessed 27 Apr 2019.

Jung Da-min. 2018. Lack of Fertilizers Adds to North Korean Agricultural Crisis. The Korea Times, August 4th, 2018. https://www.koreatimes.co.kr/www/nation/2018/08/103_253331. html. Accessed 27 Apr 2019.

KCNA. 1992. Work Progresses at Kumsong Tideland Reclamation Project, August 16th, 1992, JPRS/DTIC Document 4456/344. Accessed from www.dtic.mil.

KCNA. 1993. Widescale Reclamation of Tidelands, June 7th, 1993, JPRS/DTIC Document 4478/ 146. Accessed from www.dtic.mil.

Kim, Taekyoon. 2011. Strategizing Aid: US-China Food Aid Relations to North Korea in the 1990s. International Relations of the Asia-Pacific 12 (1): 41-70.

Lankov, Andrei, and Kim Seok-Hyang. 2008. North Korean Market Vendors: The Rise of Grassroots Capitalists in a Post-Stalinist Society. Pacific Affairs 81 (1): 53. 
Lyons, Kate, Weaver, Mathew and Haas, Benjamin. 2018. Singapore Summit: What We Learned from the Trump-Kim Meeting. BBC News, June 12th, 2018, https://www.theguardian.com/ world/2018/jun/12/singapore-meeting-what-we-know-so-far. Accessed 27 Apr 2019.

MacDonald, Hamish. 2016. Green Revolution: Sustainable Development in North Korea. NK News. October 26th, 2016. https://www.nknews.org/2016/10/green-revolution-sustainabledevelopment-in-north-korea/. Accessed 27 Apr 2019.

Makinen, Julie. 2016. Off the (failing) grid in North Korea, where Solar Energy is a Hot Commodity. Los Angeles Times, May 23rd, 2016. https://www.latimes.com/world/asia/la-fgnorth-korea-solar-snap-htmlstory.html.

Morris-Suzuki, Tessa, and Soh Eun Jeong (eds.). 2017. New Worlds from Below: Informal Life Politics and Grassroots Action in Twenty First-century Northeast Asia. Canberra: ANU Press.

Noland, Marcus. 1997. Why North Korea will Muddle Through. Foreign Affairs: 105-118.

38 North. 2012. China's Embrace of North Korea: The Curious Case of the Hwanggumpyong Island Economic Zone, 38 North, February 19th, 2012. https://www.38north.org/2012/02/ hgp021712/. Accessed 27 Apr 2019.

O'Carroll, Chad. 2017. Floating Rice Plants and Gardens Proliferate in Pyongyang. NK News, June 28th, 2017. https://www.nknews.org/2017/06/floating-rice-plants-and-gardensproliferate-in-pyongyang-photos/. Accessed 27 Apr 2019.

Park, Han S. 2007. Military-First Politics (Songun): Understanding Kim Jong Il's North Korea. Academic Paper Series on Korea 2 (7): 1-9.

Pinilla, Daniel. 2004. Border Disputes Between China and North Korea. China Perspectives 52, March-April 2004. journals.openedition.org/chinaperspectives/806. Accessed 27 Apr 2019.

Princic, Kevin. 2018. The Trouble with North Korean Ships in the Sea of Japan. cogitAsia, April 19th, 2018. https://www.cogitasia.com/the-trouble-with-north-korean-ships-in-the-sea-ofjapan/. Accessed 27 Apr 2019.

Rodong Sinmun. 1995. Constructing the Cholsan Barrage, May 23rd, 1995, JPRS/DTID Document 4123/376. Accessed from www.dtic.mil.

Rodong Sinmun. 2016. New Year Address. Rodong Sinmun, January 2nd, 2016. http://www. rodong.rep.kp/en/index.php?strPageID=SF01_02_01\&newsID=2016-01-02-0002. Accessed 29 Apr 2016.

Rodong Sinmun. 2017. New Year Address. Rodong Sinmun, January 2nd, 2017. http://rodong.rep. kp/en/index.php?strPageID=SF01_02_01\&newsID=2017-01-02-0001. Accessed 9 Jan 2017.

Rodong Sinmun. 2018a. Kim Jong Un Inspects Completed Koam-Tapchon Railways. Rodong Sinmun, May 25th, 2018. http://rodong.rep.kp/en/index.php?strPageID=SF01_02_ 01\&newsID=2018-05-25-0001. Accessed 27 Apr 2019.

Rodong Sinmun. 2018b. Kim Jong Un Inspects Fish Farms. Rodong Sinmun, July 17th, 2018. http://rodong.rep.kp/en/index.php?strPageID=SF01_02_01\&newsID=2018-07-17-0007. Accessed 27 Apr 2019.

Rodong Sinmun. 2018c. Supreme Leader Kim Jong Un Inspects Samchon Cat Fish Farm. Rodong Sinmun, August 6th, 2018. http://rodong.rep.kp/en/index.php?strPageID=SF01_02_ 01\&newsID=2018-08-06-0001. Accessed 27 Apr 2019.

Rodong Sinmun. 2018d. Supreme Leader Kim Jong Un Provides Field Guidance to Fishery Stations in Eastern Coastal Area. Rodong Sinmun, December 1st, 2018. http://rodong.rep.kp/ en/index.php?strPageID=SF01_02_01\&newsID=2018-12-01-0003. Accessed 27 Apr 2019.

Rodong Sinmun. 2018e. National Fish Breeding Laboratory Inaugurated. Rodong Sinmun, December 26th, 2018. http://rodong.rep.kp/en/index.php?strPageID=SF01_02_01\&newsID= 2018-12-26-0010. Accessed 27 Apr 2019.

Rodong Sinmun. 2018f. Kim Jong Un Visits Sindo County, North Phyongan Province. Rodong Sinmun, June 30th, 2018. http://rodong.rep.kp/en/index.php?strPageID=SF01_02_ 01\&newsID=2018-06-30-0010. Accessed 27 Apr 2019.

Shim, Elizabeth. 2016. North Korea Sold \$30 Million of Fishing Rights to Chinese Vessels Seoul Says, UPI, July 1st, 2016. https://www.upi.com/Top_News/World-News/2016/07/01/NorthKorea-sold-30M-of-fishing-rights-to-Chinese-vessels-Seoul-says/2611467386956/. Accessed 27 Apr 2019. 
Sigley, Alek. 2019. I'm the Only Australian Living in North Korea. Let Me Tell You About It, The Guardian, March 31st, 2019. https://www.theguardian.com/commentisfree/2019/mar/31/imthe-only-australian-living-in-north-korea-let-me-tell-you-about-it. Accessed 27 Apr 2019.

Smith, Hazel. 2009. North Korea: Market Opportunity, Poverty and the Provinces. New Political Economy. 14 (2): 231-256.

Theo Clement. 2016. One More for the Road? New Masterplan for the Sinuiju Special Economic Zone, Sino-NK, February 11th, 2016. https://sinonk.com/2016/02/11/one-more-for-the-roadnew-masterplan-for-the-sinuiju-special-economic-zone/. Accessed 27 Apr 2019.

Townsend, Alan, and Robert W. Howarth. 2010. Fixing the Global Nitrogen Problem. Scientific American 302 (2): 64-71.

UNEP Regional Seas. 2011. Integrated Report on Eutrophication Assessment in Selected Sea Areas in the NOWPAP Region: Evaluation of the NOWPAP Common Procedure. Toyama: UNEP Regional Seas.

United Nations. 2017a. UN Security Council Resolution 2371. August 5th, 2017. http://unscr.com/ en/resolutions/doc/2371. Accessed 27 Apr 2019.

United Nations. 2017b. UN Security Council Resolution 2397. 22nd December, 2017. http://unscr. com/en/resolutions/doc/2397. Accessed 27 Apr 2019.

United States Congress. 2016. H.R.757-North Korea Sanctions and Policy Enhancement Act of 2016. US Congress (House of Representatives). https://www.congress.gov/bill/114th-congress/ house-bill/757. Accessed 27 Apr 2019.

Wang, Qing, Shuqing An, Zhijun Ma, Bin Zhao, Jiakuan Chen, and Bo Li. 2006. Invasive Spartina Alterniflora: Biology, Ecology and Management. Acta Phytotaxonomica Sinica 44 (5): 559_ 588.

Winstanley-Chesters, Robert. 2014. Environment, Politics and Ideology in North Korea: Landscape as Political Project. Lanham, MD: Lexington Press.

Winstanley-Chesters, Robert. 2016. Politics and Pollack: Maritime Policy Under the Kims. In Change and Continuity in North Korean Politics, ed. R. Winstanley-Chesters, A. Cathcart, and C. Green. London: Routledge.

Zhou, Mingjiang, Mingyuan Zhu, and Jing Zhang. 2001. Status of Harmful Algal blooms and Related Research Activities in China. Chinese Bulletin of Life Sciences 13 (2): 54-59.

Open Access This chapter is licensed under the terms of the Creative Commons Attribution 4.0 International License (http://creativecommons.org/licenses/by/4.0/), which permits use, sharing, adaptation, distribution and reproduction in any medium or format, as long as you give appropriate credit to the original author(s) and the source, provide a link to the Creative Commons license and indicate if changes were made.

The images or other third party material in this chapter are included in the chapter's Creative Commons license, unless indicated otherwise in a credit line to the material. If material is not included in the chapter's Creative Commons license and your intended use is not permitted by statutory regulation or exceeds the permitted use, you will need to obtain permission directly from the copyright holder. 